\title{
一般口演 13
}

\section{構音を利用した舌後方部筋活動標準化の一手法 一咀嚼・嚥下時の舌運動客観評価のために一}

A method for standardizing muscle activity of posterior tongue using articulation

○萬田陽介, 兒玉直紀, 前田直人, 川上滋央, 森慧太朗, 北川佳祐, 古寺寛志, 皆木省吾

Yosuke Manda, Naoki Kodama, Naoto Maeda, Keitarou Mori, Keisuke Kitagawa, Shogo Minagi

岡山大学大学院医歯薬学総合研究科咬合·有床義歯補綴学分野

Department of Occlusal and Oral Functional Rehabilitation

Okayama University Graduate School of Medicine, Dentistry and Pharmaceutical Sciences

\section{I. 目的}

舌の運動・機能の重要性は広く知られるところである が，その活動実態は未だ十分に解明されるに至っていな い. 我々はこれまで, 頸部の表面筋電図を利用した簡便 かつ非侵襲的な機能評価手法 (以下, N-EMG) につい て報告してきた ${ }^{1)}$. 筋電図の量的因子を解析するために は活動量の標準化が必要であるが, N-EMGに関しては 標準化手法は未だ確立されていない，筋電図を標準化す るデータに求められる条件として再現性が高いことが挙 げられる. 今回我々は再現性の高い舌運動として構音に 着目し, 将来的な N-EMGの標準化に向けて構音時の舌 圧㧍よび筋活動量について検討を行うこととした。

\section{II. 方 法}

\section{1. 対象}

顎口腔系に異常のない20名の健常成人（男性 10 名, 女性 10 名, 平均年齢 $26.9 \pm 2.3$ 歳）を対象として, 構音 時の舌圧およびN-EMGを記録した。なお，本研究は岡 山大学倫理審査委員会で承認を受けて実施した（承認番 号 臨1709-008).

\section{2. 表面電極貼付位置}

Manda ら ${ }^{1,2)}$ の報告に従って, 胸鎖乳突筋前縁, 下顎 骨下縁，顎舌骨筋後縁に囲まれた三角形の中に，下顎骨 下縁の垂線が通る位置に表面電極を貼付した（図 1 ). 電極は左右両側に設置した。

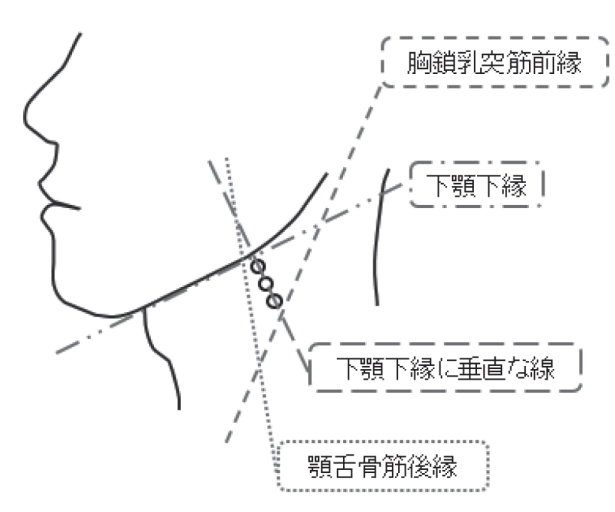

図 1 表面電極の貼付位置

\section{3. 被験音}

構音時に舌後方部が口蓋に接触する $/ \mathrm{ka} /, / \mathrm{ko} /$, /ga/, / / go/を被験音とした。構音時の声量はデジタル 騒音計（TESTO816, Testo SE \& Co）にて測定し, 被 験音をそれぞれ $70 \mathrm{~dB}, 60 \mathrm{~dB}, 50 \mathrm{~dB}, 40 \mathrm{~dB}$ の大きさで, 1 秒間隔で 10 回ずつ発声させた。

\section{4. 舌圧}

構音時の舌圧を測定するために, 口蓋に圧力センサ (PSM-1KAB，共和電業）を設置した。センサの設置位 置は, 構音時の舌と口蓋の接触箇所を目視にて確認し, 決定した。センサは両側に設置した。この手法による構 音時の舌圧測定の信頼性，再現性を検証するために， 1 回目の測定から 3 日以上経過した後に舌圧のみ 2 回目の 測定を行った。 


\section{5. 解析}

解析には 10 回の構音のうち, 最初と最後の 2 回ずつ を除いた 6 回の舌圧・筋電図波形のピーク值を用いた。

構音時の舌圧の筋電図波形の最大振幅值について, 日 間変動による舌圧データの繰り返し測定の再現性を変動 係数を用いて検討した。また各被験音において, 舌圧 の日間変動が少ない 60-50 dB，50-40 dB の 2 条件下の デー夕を対象として両日間で舌圧の值が近似するデータ （誤差範囲士5％）を選定し, 各条件において発生した 最大筋活動量を用いて相関関係を検討した。

\section{III. 結 果}

すべての被験音, 声量に扔ける舌圧デー夕の変動係数 は $0.36<\mathrm{CV}<0.49$ となり, 日間変動が大きいことが示唆 されたその中で比較的日間変動が少ない $/ \mathrm{ko} /, / \mathrm{go} /$ の 60-50 dB 間抒よび50-40 dB 間で舌圧が近似してい るデー夕を選定（誤差範囲土0.5）し, その際に発生し た筋活動の最大振幅值により散布図を作成したところ, $/ \mathrm{ko} /$ の 60-50 dB 間では強い正の相関を認めた $(\mathrm{r}=0.75$, 図2).

\section{N. 考 察}

舌圧データの日間変動について変動係数を用いて検討 したところ，全被験音において変動係数は高值を示し， 再現性が低いことが示された。本研究では 1 秒間隔で構 音を行わせたが, 再現性の高い舌圧デー夕を記録するた めには構音の間隔を 1 秒以下にするなどの工夫が必要で あると考えられる. また, 本研究では 10 回の構音のうち, 最初と最後の 2 回ずつを除いた 6 回のデー夕を解析対象 としたが, 記録データの観察から, 研究対象者が構音に 慣れた後半 5 回からデー夕を抽出する方が再現性が高 い可能性が考えられた。また $/ \mathrm{ka} /, / \mathrm{ga} /$ は $/ \mathrm{ko} /, / \mathrm{go} /$ と比較して舌圧の日間変動が大きい傾向にあった。これ は, 母音の発声様式により / ka/, / ga/の繰り返し発生 では舌の運動量が多くなり, 口蓋との接触により発生す る圧が不安定となった可能性が考えられる。

比較的日間変動の小さい $/ \mathrm{ko} /, / \mathrm{go} /$ の 60-50 dB 間, 50-40 dB 間では日間変動が少ない傾向にあり, さらに 舌圧は近い值を示す傾向にあった。このことから，60-

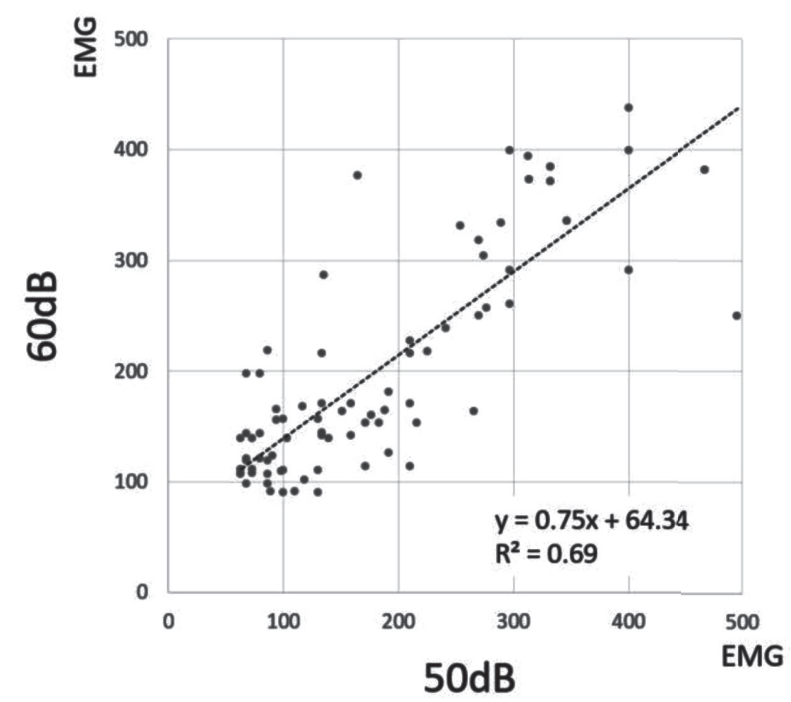

図 2 異なる声量間で舌圧が近似した際の筋活動量を基に作成 した散布図および回帰直線 (/ko/ 発声時)

$40 \mathrm{~dB}$ 間の声量では，声量が必ずしも舌圧に影響を及ぼ さないと考えられる，さらに，被験音 $/ \mathrm{ko} /$ に扔いては 60-50 dB 間で舌圧の值が近いデータセットにおいては, その際に発生した筋活動量に強い正の相関を認めた。こ れにより, /ko/ 発音時の60-50 dB 間条件下においては, 舌圧が等しければ，声量の大きさに関わらず筋活動量が 近似した值をとる傾向が強いことが示された。

本研究では構音により日間変動が少ない舌圧データを 記録することができなかったが，プロトコルの改善によ り再現性の高いデー夕を記録できることが示唆された. N-EMGno 標準化に向けて, 今後より再現性の高いデー 夕を記録し正常像に関する定量的・客観的デー夕の蓄積 に努めたい.

\section{V. 文献}

1) Manda Y, Maeda N, Pan Q, Sugimoto K, Hashimoto Y, Tanaka Y, Kodama N, Minagi S. New method of neck surface electromyography for the evaluation of tongue-lifting activity. J Oral Rehabil. 2016 Jun; 43(6): 417-25 